\title{
Pendidikan Orang Tua Terhadap Anak dalam Menyikapi Pandemi COVID-19
}

\author{
Muhammad Candra Syahputra
}

Mahasiswa Pascasarjana UIN Sunan Ampel Surabaya candrasyach@gmail.com

•Received: 25 April 2020 •Accepted: 19 Mei 2020 •Published online: 30 Juni 2020

\begin{abstract}
Abstrak :
Coronavirus Disease (COVID-19) adalah wabah virus yang menjakit masyarakat dunia atau disebut pandemi, sejak ditemukan kasus positif COVID-19 di Indonesia pada 2 Maret 2020 pemerintah Republik Indonesia mengumumkan Indonesia darurat COVID-19, yang juga berdampak pada kegiatan belajar mengajar di sekolah maupun madrasah. Sekolah dan madrasah dirumahkan untuk melakukan kegiatan belajar di rumah dengan melakukan pembelajaran dalam jaringan. Guru sebagai pendidik selain tetap memberikan materi dalam proses belajar-mengajar jarak jauh melalui jaringan internet, juga harus bekerjasama dengan orang tua dalam mengawasi kegiatan belajar mengajar, selain itu orang tua juga hendaknya memberikan edukasi tentang dampak COVID-19 dan juga cara pencegahannya. Penelitian ini menggunakan pendekatan kualitatif dengan metode penelitian kepustakaan dengan mengandalkan sumber-sumber kepustakaan yang kemudian di analisis secara mendalam untuk mengetahui betapa pentingnya peran orang tua dalam mengedukasi anak-anaknya tentang dampak COVID-19 dan cara pencegahannya, melakukan kontrol terhadap anak melalui pengawasaan agar tidak bermain diluar rumah, bekerjasama dengan guru mengawasi kegiatan belajar-mengajar anak, menanamkan nilai karakter dalam menyikapi pandemi COVID-19.
\end{abstract}

Kata Kunci: Pandemic, Covid-19, Family Education

\begin{abstract}
Coronavirus Disease (COVID-19) is a virus outbreak that infected the world community or is called a pandemic, since founding positive cases of COVID-19 in Indonesia on march 2 2020, the government of the Republic of Indonesia announced Indonesia emergency COVID-19, which also has an impact on teaching and learning activities in schools and madrasas. Schools and madrassas were home to conduct learning activities at home by doing learning in the network. Teachers as educators in addition to continuing to provide material in the process of teaching and learning distance through the internet network, also must work together with parents in supervising teaching and learning activities, besides that parents should also provide education about the impact of COVID-19 and also how to prevent it. This study uses a qualitative approach to library research methods by relying on library sources which are then analiyzed in depth to find out how important
\end{abstract}


the role of parents is in educating their children about the impact of COVID-19 an how to prevent it, exercise control over the child through supervision so as not to play outside the home, in collaboration with the teacher supervising children's teaching and learning activities, instill character values in responding to the COVID-19 pandemic.

Keywords: Pandemic, Covid-19, Family Education.

\section{A. PENDAHULUAN}

Pandemi Coronavirus Disease (COVID-19) merupakan wabah dunia yang sangat ekstrem persebarannya, kita semua warga Negara Kesatuan Republik Indonesia bahkan warga Dunia, tidak pernah menyangka akan mengghadapi wabah yang menyebabkan sindrom pernafasan akut pada penderitanya, dan telah banyak menelan korban jiwa diberbagai negara belahan dunia yang juga menimbulkan keresahan. Sebelum muncul coronavirus baru, pada 2018 telah terjadi kasus coronavirus dengan nama Middle East Respiratory Syndrom Coronavirus (MERS-CoV) di daerah Jazirah Arab (Pradanti 2019:197-206). Sebelum pandemi COVID-19 tersebar ke berbagai negara di dunia, pada bulan Desember 2019 ditemukannya kasus pneumonia misterius yang pertama kali dilaporkan di Kota Wuhan, Provinsi Hubei. Belum dikelahui secara pasti sumber penularan kasus ini, tetapi kasus pertama dikaitkan dengan pasar ikan yang terletak di kota Wuhan.

Pada tanggal 18 Desember hingga 29 Desember 2019, terdapat pasien berjumlah 5 orang yang dirawat dengan Acute Respiratory Distress Syndrome (ARDS). Sejak tanggal 31 Desember 2019 hingga 1 Januari 2020 kasus ini meningkat begitu pesat, ditandai dengan dilaporkannya sebanyak 44 kasus, bahkan belum mencapai satu bulan kasus ini telah menyebar di berbagai provinsi di Cina, dan negara-negara lain seperti Jepang, Thailand, dan Korea Selatan (Susilo dkk. 2020:45).

Sampel yang diteliti menunjukkan etiologi coronavirus baru. Awalnya penyakit ini dinamakan sementara sebagai 2019 Novel Coronavirus (2019-nCOV), kemudian World Health Organization (WHO) mengumumkan nama baru pada 11 Februari 2020 yaitu Coronavirus Disease (COVID-19) yang disebabkan oleh virus Severe Acute Respiratory Syndrome Coronavirus-2 (SARS-CoV-2). COVID-19 merupakan infeksi virus baru yang menginfeksi saluran pernafasan dari gejala umum berupa demam, batuk, dan sulit bernafas (Yuliana 2020:192). Virus ini dapat ditularkan dari manusia ke manusia dan telah menyebar luas di Cina dan berbagai negara di belahan dunia (Susilo dkk. 2020:45). Kasus positif COVID-19 di Indonesia diumumkan pada 2 Maret 2020, dan tidak lama kemudian Indonesia ditetapkan sebagai darurat COVID-19. Pada 12 Maret 
2020 WHO mengumumkan COVID-19 sebagai pandemic, keadaan darurat secara global (Sohrabi dkk. 2020:71-72).

Pemerintah Indonesia terus melakukan upaya-upaya guna meminimalisir orangorang yang terinfeksi COVID-19. Mengantisipasi dan mengurangi jumlah penderita COVID-19 di Indonesia sudah dilakukan di berbagai daerah. Diantaranya dengan memberikan kebijakan membatasi aktifitas keluar rumah (Yunus dan Rezki 2020:228). Badan Nasional Penanggulangan Bencana (BNPB) mengumuknan pandemi COVID-19 sebagai bencana Nasional. kebijakan untuk menghindari keramaian dengan jaga jarak sosial (social distancing) dan jarak fisik (psychal distancing) dengan menganjurkan untuk beribadah di rumah,.bekerja dari rumah, dan belajar di rumah sampai pada kebijakan Pembatasan Sosial Berskala Besar (PSBB) yang telah diterapkan di beberapa daerah di Indonesia.

Jumlah kasus positif COVID-19 di Indonesia terus bertambah dan secara serentak viral hashtag \#DiRumahAja di berbagai sosial media seperti Twitter, Facebook, Instagram, WhatsApp dan lainnya sebagai gerakan masyarakat menyambut dan mendukung kebijakan pemerintah Republik Indonesia. Merebaknya COVID-19 di Indonesia berdampak pada beberapa sektor seperti ekonomi, pariwisata, sampai sektor pendidikan, yang menyebabkan sekolah, madrasah, dan perguruan tinggi diberlakukan pembelajaran jarak jauh dalam jaringan dengan memanfaatkan teknologi informasi dan komunikasi.

Dengan kebijakan belajar dari rumah, pemerintah Republik Indonesia melalui Kementrian Pendidikan dan Kebudayaan, para guru mengajar melalui media teknologi informasi dan komunikasi melalui jaringan internet atau yang sering disebut e-learning (Daryanto 2015:162). Dengan memanfaatkan fitur Personal Computer, Tablet PC, ataupun Smartphone misalnya dengan videocall atau memanfaatkan grup kelas online (Arsyad 2015:194-95).

Tidak hanya memberikan materi-materi pelajaran kepada peserta didik, guru juga harus memberikan pemahaman kepada peserta didik tentang pandemi COVID-19 dan cara mencegahnya, agar peserta didik tidak hanya belajar dirumah, tetapi juga agar berkegiatan di rumah untuk memutus mata rantai persebaran COVID-19. Kemudian, guru juga harus bekerjasama dengan orang tua peserta didik dalam memberikan pemahaman kepada peserta didik tentang COVID-19, dikarenakan orang tua lah yang membersamai peserta didik secara langsung saat di rumah. 
Hal diatas berdasarkan peran guru sebagai komunikator karena menyangkut proses penyampaian informasi dari guru kepada orang tua peserta didik (Rusman 2014:61-62) dikarenakan peran keluarga sangat besar dalam memberikan sosialisasi berupa pemahaman tentang tujuan belajar dari rumah kepada anak-anaknya dalam menyikapi pandemi COVID-19. Dengan, demikian saat merebaknya wabah pandemi COVID-19 ini orang tua hendaknya memberikan pendidikan kepada anak-anaknya yaitu melalukan kerjasama dengan guru agar tercapainya proses pembelajaran dengan baik di rumah.

Sebagai institusi pertama tempat berlangsungnya proses pendidikan anak, maka orang tua sebagai penanggung jawab pendidikan keluarga harus benar-benar dapat menyikapi kenyataan ini dengan mengondisikan lingkungan keluarga dengan suasana pendidikan yang dilaksanakan melalui pengajaran, pembiasaan, dan keteladanan (Wahy 2012:256). Dalam hal ini para orang tua selain melakukan pengawasan belajar dirumah juga membimbing anak-anaknya untuk senantiasa menjaga kebersihan lingkungan, menjaga kesehatan, rajin berolahraga dalam menyikapi COVID-19 yang nantinya dapat menjadi kebiasaan yang baik, dan tidak lupa juga orang tua tidak hanya sekedar memberikan pengarahan, namun ikut juga melakukan anjuran pemerintah dengan melakukan tindakan preventif agar menjadi tauladan bagi anak-anaknya.

Orang tua merupakan panutan bagi anak-anaknya, untuk itu sebaiknya orang tua dapat menjadi contoh yang baik bagi anak-anaknya (Agustin, Suarmini, dan Prabowo 2015:54). Pendidikan anak dalam keluarga mencakup seluruh aspek dan melibatkan semua anggota keluarga, mulai dari bapak, ibu, dan anak-anak. Namun, yang lebih penting adalah pendidikan itu wajib diberikan oleh orang tua kepada anak-anaknya (Andriyani 2018:791). Orang tua tidak hanya sekedar membangun silaturahmi dan melakukan berbagai tujuan keluarga seperti reproduksi, meneruskan keturunan, menjalin kasih sayang dan sebagainya (Jailani 2014:247).

Oleh karenanya, penulis merasa perlu mengulas dan mengkaji Pendidikan Orang Tua Terhadap Anak dalam Menyikapi Pandemi COVID-19 yaitu dalam hal pengawasan anak-anak untuk tetap belajar dirumah, dan mengedukasi tentang COVID-19 mengingat persebarannya sangat ekstrem.

\section{B. METODOLOGI PENELITIAN}

Pendekatan yang digunakan dalam penelitian ini adalah pendekatan kualitatif (Dyah 2005:25). Alasan menggunakan penelitian kualitatif dikarenakan, penelitian ini 


\section{Nama penulis}

dilakukan untuk memperoleh gambaran secara mendalam mengenai objek penelitian yaitu bagaimana "Pendidikan Orang Tua Terhadap Anak dalam Menyikapi Pandemi COVID-19". Oleh karena itu penulis dalam penelitian ini memilih pendekatan kualitatif. Metode penelitian dalam penelitian dilakukan dengan cara deskriptif-kualitatif dengan menggunakan kajian pustaka (library research). Penelitian ini merupakan penelitian kepustakaan, mencari dan menyitir dari bermacam-macam sumber data yang berkaitan dengan permasalahan yang diteliti berupa dokumen kepustakaan (Sukardi 2015:34). Kajian pustaka adalah proses kegiataan menelaah bahan-bahan pustaka tersebut (Sanjaya 2015:205), penelitian ini menyesuaikan kebijakan pemerintah agar tidak keluar rumah, maka penulis tanpa melalui penelitian yang dilakukan di lapangan, Penulis dalam penelitian ini menekankan pada kekuatan analisis sumber-sumber dan data-data yang ada dengan mengandalkan teori-teori dan konsep-konsep untuk kemudian di interpretasikan berdasarkan tulisan-tulisan yang relevan pada pembahasan.

\section{PEMBAHASAN DAN HASIL PENELITIAN}

Pendidikan sudah pasti berkenaan terhadap pengembangan kognitif atau pengetahuan, afektif atau sikap, dan psikomotorik atau perilaku. Pendidikan erat kaitannya dengan proses perpindahan atau transfer pengetahuan, sikap, keterampilan, kepercayaan, dan aspek perilaku lainnya kepada generasi muda. Pendidikan adalah proses pembelajaran pola-pola perilaku individu berdasarkan apa yang menjadi harapan masyarakat. Menurut Nasution, perbuatan atau perilaku manusia hampir keseluruhan bersifat sosial, dapat dipelajari dalam proses interaksi individu yang satu dengan lainnya.

Hampir semua yang kita pelajari adalah hasil dari hubungan atau interaksi kita dengan sesama baik yang dilakukan di lingkungan keluarga atau rumah, lingkungan sekolah atau madrasah, lingkungan masyarakat seperti tempat permainan, pekerjaan, dan lain sebagainya. Dengan meminjam istilah Ki Hadjar Dewantara lingkungan pendidikan disebut sebagai Tri Pusat Pendidikan (Ki Hadjar Dewantara 1977:70-73) yaitu lingkungan keluarga, lingkungan masyarakat, dan lingkungan sekolah. Ketiganya tidak dapat dipisahkan dalam proses pendidikan karena merupakan sebuah satu-kesatuan yang terpaut satu sama lain dalam transfer pengetahuan, pembentukan sikap, dan juga perilaku anak sebagai peserta didik. 


\section{Muhammad Chandra Syahputra}

Bahkan isi dari pelajaran dalam pendidikan juga ditentukan oleh kelompok atau masyarakat tempat dimana peserta didik melaksanakan pendidikan, dalam pengertian tersebut memberikan pemahaman bahwa sesungguhnya pendidikan telah dimulai sejak seseorang individu pertama kali melakukan proses interaksi dengan lingkungan keluarga (Maksum 2016:51-52).

Dalam konteks kehidupan di Indonesia, Ki Hajar Dewantara mengemukakan bahwa keluarga merupakan kumpulan beberapa orang yang terikat oleh satu gabungan yang khas, pun berkehendak juga untuk bersama-sama memperteguh gabungan itu untuk kemuliaan satu-satunya dan semua anggota (Supriyono, Iskandar, dan Sucahyono 2015:6). Keluarga juga memiliki fungsi dalam mengasuh, mensosialisasikan sesuatu kepada anak, mendidik juga mengembangkan kemampuan tiap-tiap anggota keluarga agar dapat menjalankan fungsinya dengan baik dalam masyarakat, serta memberikan rasa puas terhadap aspek penting guna internalisasi nilai karakter pada anak sehingga memiliki karakter yang baik (Kurniawan 2013:43-45).

Keluarga senantiasa disebut sebagai lembaga pendidikan yang pertama dan utama. Cakupan makna pertama dan utama tidak hanya dalam dimensi waktu atau kronologis proses terjadinya pendidikan namun juga dalam dimensi tanggung jawab. Betapapun proses pendidikan telah diselenggarakan oleh berbagai lembaga pendidikan formal maupun non-formal, secara sosio-historis kehadiran lembaga-lembaga pendidikan professional itu merupakan pengganti peran atas peran lembaga keluarga sebagai pendidikan yang utama tadi. Dengan demikian jelas dapat dikatakan lembaga pendidikan professional itu menerima mandate dari lembaga keluarga untuk menyelenggarakan pendidikan bagi para anggota keluarga (Supriyono dkk. 2015:2).

Dalam hal ini, anak merupakan anggota keluarga yang menjadi tanggung jawab kedua orang tuanya yang harus dijaga, dirawat, dibesarkan dan diberikan hak pendidikan oleh orang tuanya baik pendidikan di lingkungan keluarga, maupun pendidikan formal disekolah. Anak adalah amanah yang harus dipertanggungjawabkan orang tua kepada Allah SWT. Anak adalah tempat orang tua mencurahkan kasih sayangnya, dan juga merupakan investasi masadepan untuk kepentingan orang tua di akhirat kelak. Oleh sebab itu orang tua harus memelihara, membesarkan, merawat, menyantuni dan mendidik anak-anaknya dengan penuh tanggung jawab dan kasih sayang (Ilyas 2000:172).

Keluarga sebagai salah satu lingkungan pendidikan, tentunya memungkinkan melakukan proses pendidikan sebagai pendidikan in-formal dalam kesehariannya. 


\section{Nama penulis}

Keluarga dalam menyikapi Pandemi COVID-19 dapat melakukan edukasi terhadap anggotanya, sebagai bentuk mendukung kebijakan pemerintah Republik Indonesia dengan beribadah dirumah, bekerja dari rumah, dan belajar dari rumah dengan melakukan hal-hal sebagai berikut:

Pertama, orang tua berperan aktif dalam mengawasi peserta didik di rumah dengan memberikan pemahaman kepada peserta didik melalui nasihat tentang pandemi COVID-19 berupa dampak yang disebabkannya, cara persebaran dan penularannya, dan langkah-langkah mencegah maupun memutus mata rantai pandemi COVID-19. Pendidikan keluarga tidak hanya berhenti pada proses transfer pengetahuan saja. Akan tetapi juga dengan praktik langsung seperti orang tua mengajak anak-anaknya untuk melakukan pola hidup bersih dan sehat, orang tua mengajak anak-anak untuk melakukan tindakan preventif dalam mencegah persebaran pandemi COVID-19 dengan mencuci tangan menggunakan sabun, tidak berkegiatan diluar rumah kecuali keadaan penting, apabila dirasa penting untuk keluar rumah maka wajib menggunakan masker, beribadah dirumah bersama-sama, berikhtiar (berusaha dan berdo'a) agar terhindar dari infeksi Pandemi COVID-19.

Kedua, keluarga sebagai kontrol sosial dalam menghadapi pandemi COVID-19. Anak-anak dengan segala tingkah lakunya cenderung bosan berkegiatan dirumah, tugas orang tua juga selain mengawasi juga menjaga anak-anak agar tidak bermain diluar rumah dengan teman-temannya, atau justru bermain game playstation dengan temantemannya diluar rumah. dengan diliburkannya anak-anak sekolah, jangan sampai mereka bermain di warnet dan tempat-tempat ramai lainnya. Dengan demikian peran penuh orang tua hiharapkan dalam mengawasi dan menjaga anak-anaknya dalam menghadapi pandemi COVID-19.

Ketiga, orang tua juga harus memberikan pengarahan dan pengawasan anak-anak dalam menjalani kegiatan belajar dirumah, seperti pengawasan saat pembelajaran dalam jaringan (Daring) dilaksanakan dengan cara memanfaatkan fasilitas jaringan internet, pengarahan dan pengawasan tersebut agar anak-anak selain memanfaatkan jaringan internet untuk proses pembelajaran juga agar anak-anak memanfaatkan internet dengan positif dan terhindar dari konten-konten negatif.

Keempat, orang tua harus menanamkan nilai-nilai karakter yang luhur kepada anakanaknya secara terus menerus, termasuk dalam menyikapi pandemi COVID-19 untuk menanamkan sikap tenang dan tidak panik agar tidak menimbulkan keresahan, kemudian menanamkan sikap kemanusiaan, walaupun harus menjaga jarak orang tua 


\section{Muhammad Chandra Syahputra}

memberikan pemahaman agar anak-anak tidak mengucilkan penderita COVID-19, hal ini penting dikarenakan di beberapa daerah di Indonesia pasien COVID-19 dikucilkan, bahkan terjadinya penolakan jenazah penderita COVID-19 oleh warga saat akan dikebumikan.

Proses tersebut diatas tidak hanya menunjukkan peran keluarga sebagai salah satu lingkungan pendidikan untuk transfer ilmu pengetahuan semata, namun dengan ini akan menumbuhkan sikap emosional yang tinggi antar keluarga sehingga terciptanya harmoni dalam kehidupan berkeluarga dengan memupuk solidaritas satu-sama lain dalam menghadapi Pandemi COVID-19 dan sesudahnya agar terwujudnya keluarga sakinah mawaddah wa rahmah.

\section{KESIMPULAN}

Keluarga sebagai lembaga pendidikan pertama atau bahkan disebut lembaga pendidikan seumur hidup dalam melakukan proses pendidikan keluarga tidak terlepas dari peran orang tua. Orang tua menjadi panutan dan kebanggaan bagi putra-putrinya. Peran orang tua dalam memberikan pendidikan berupa pemahaman, pembiasaan, dan tauladan ke pada anak sangat penting dalam menyikapi pandemi COVID-19, dengan memberikan pemahaman tentang dampak pandemi COVID-19 berikut pencegahannya, orang tua mengawasi dan menjaga anak-anaknya agar tidak bermain diluar rumah, bekerjasama dengan guru melakukan pengawasan anak saat belajar dirumah, penananaman nilai karakter luhur kepada anak dalam menyikapi pandemi COVID-19.

\section{REFERENCES}

Agustin, Dyah Satya Yoga, Ni Wayan Suarmini, dan Suto Prabowo. 2015. "Peran Keluarga Sangat Penting dalam Pendidikan Moral, Karakter Anak serta Budi Pekerti Anak." JSH: Jurnal Sosial Humaniora Vol. 8 No. 1.

Andriyani, Isnanita Noviya. 2018. "Pendidikan Anak di Era Digital." FIKROTUNA: Jurnal Pendidikan dan Manajemen Islam Vol. 7 No. 1.

Arsyad, Azhar. 2015. Media Pembelajaran. Jakarta: Rajawali Pers.

Daryanto. 2015. Media Pembelajaran. Bandung: Satu Nusa.

Dyah, H. M. 2005. Penelitian Kualitatif Dalam Penerapan. Pekanbaru: Depdiknas Pusat Bahasa.

Ilyas, Yunahar. 2000. Kuliah Akhlaq. Yogyakarta: LPPI UMY.

Jailani, M. Syahran. 2014. “Teori Pendidikan Keluarga dan Tanggung Jawab Orang Tua dalam Pendidikan Anak Usia Dini." Nadwa: Jurnal Pendidikan Islam Vol. 8 No. 2.

Ki Hadjar Dewantara. 1977. Pendidikan Bagian Pertama. Yogyakarta: Majelis Luhur 
Nama penulis

Taman Siswa.

Kurniawan, Syamsul. 2013. Pendidikan Karakter: Konsepsi \& Implikasi Secara Terpadu di Lingkungan Keluarga, Sekolah, Perguruan Tinggi, \& Masyarakat. Yogyakarta: Ar-Ruzz Media.

Maksum, Ali. 2016. Sosiologi Pendidikan. Malang: Madani.

Pradanti, Della Safera. 2019. "Evaluation Of Formal Risk Assesment Implementation of Middle East Respiratory Syndrome Coronavirus In 2018." JBE: Jurnal Berkala Epidemiologi Vol 7(3).

Rusman. 2014. Model-Model Pembelajaran: Mengembangkan Profesionalisme Guru. Edisi Kedua. 2014: Rajawali Pers.

Sanjaya, Wina. 2015. Penelitian Pendidikan: Jenis, Metode dan Prosedur. Jakarta: Prenada Media Group.

Sohrabi, Catrin, Zaid Alsafi, Niamh O'Neill, Mehdi Khan, Ahmed Kerwan, Ahmed Al-Jabir, Chirtos Iosifidis, dan Riaz Agha. 2020. “World Health Organization Declares Global Emergency: A Review of the 2019 Novel Coronavirus (COVID-19)." International Journal of Surgery Vol. 76.

Sukardi. 2015. Metodologi Penelitian Pendidikan: Kompetensi dan Praktiknya. Jakarta: Bumi Aksara.

Supriyono, Haris Iskandar, dan Sucahyono. 2015. Pendidikan Keluarga dalam Perspektif Masa Kini. Jakarta: Direktur Jenderal Pendidikan Anak Usia Dini dan Pendidikan Masyarakat.

Susilo, Adityo, C. Martin Rumende, Ceva W. Pitoyo, Widayat Djoko Santoso, Mira Yulianti, Herikurniawan, Robert Sinto, Gurmet Singh, Leonard Nainggolan, Emi J. Nelwan, Lie Khie Chen, Alvina Widhani, Edwin Wijaya, Bramantya Wicaksana, Mardewi Maksum, Firda Annisa, Chyntia OM Jasirwan, dan Evy Yunihastuti. 2020. “Coronavirus Disease 2019: Tinjauan Literatur Terkini." Jurnal Penyakit Dalam Indonesia Vol. 7 No. 1.

Wahy, Hasbi. 2012. “Keluarga Sebagai Basis Pendidikan Pertama dan Utama.” Jurnal Ilmiah DIDAKTIKA Vol. XII No. 2.

Yuliana. 2020. "Corona Virus Disease (Covid-19); Sebuah Tinjauan Literatur." Wellness And Healthy Magazine, Februari.

Yunus, Nur Rohim, dan Annissa Rezki. 2020. “Kebijakan Pemberlakuan Lockdown Sebagai Antisipasi Penyebaran Corona Virus Covid-19." SALAM: Jurnal Sosial \& Budaya Syar'i Vol. 7 No. 3. 